\title{
PENGARUH METODE CIRCUIT LEARNING PADA MATA PELAJARAN EKONOMI DI SMA
}

\author{
Lia Desiana1, Rita Patonah², Ilah ${ }^{3}$ \\ 1,2,3 Program Studi Pendidikan Akuntansi, Universitas Galuh, Jl. R. E. Martadinata No.150, Ciamis, Indonesia \\ Email: liadesiana98@gmail.com, ritadearly@gmail.com, ilahmulyadi.im@gmail.com
}

\begin{abstract}
The low learning outcomes of students in class X Social Studies at SMA Negeri 1 Pamarican are thought to be due to the lack of new breakthroughs in the use of learning methods. Circuit Learning learning method is applied as an effort to improve learning outcomes. The purpose of this study was to determine the differences: 1) the learning outcomes of students using the Circuit Learning learning method in the pretest and posttest. 2) learning outcomes of students using conventional methods on pretest and posttest. 3) learning outcomes of students using the Circuit Learning learning method with those using conventional methods at the posttest. The method used is an experimental method with a Quasi Experimental Nonequivalent Control Group Design. The data analysis technique used is the test. The results of the study show that: 1) There are differences in the learning outcomes of students who use the Circuit Learning learning method in the pretest and posttest; 2) There are differences in student learning outcomes using conventional methods in the pretest and posttest; 3) The learning outcomes of students using the Circuit Learning method are different from those using conventional methods during the posttest.
\end{abstract}

Keywords: circuit learning learning method, learning outcomes

\begin{abstract}
ABSTRAK
Rendahnya hasil belajar peserta didik di kelas X IPS SMA Negeri 1 Pamarican diduga disebabkan kurangnya terobosan baru dalam penggunaan metode pembelajaran. Metode pembelajaran Circuit Learning diterapkan sebagai upaya untuk meningkatkan hasil belajar. Tujuan penelitian ini untuk mengetahui perbedaan: 1) hasil belajar peserta didik yang menggunakan metode pembelajaran Circuit Learning pada pretest dan posttest. 2) hasil belajar peserta didik yang menggunakan metode konvensional pada pretest dan posttest. 3) hasil belajar peserta didik yan menggunakan metode pembelajaran Circuit Learning dengan yangg menggunakan metode konvensional pada saat posttest. Metode yang digunakan yaitu metode eksperimen dengan desain Quasi Eksperimental Nonequivalent Control Group Design. Teknik analisis data yang digunakan yaitu uji t. Hasil penelitian menunjukan bahwa: 1) Terdapat perbedaan hasil belajar peserta didik yang menggunakan metode pembelajaran Circuit Learning pada pretest dan posttest; 2) Terdapat perbedaan hasil belajar peserta didik yang menggunakan metode konvensional pada pretest dan posttest; 3) Hasil belajar peserta didik yang menggunakan metode Circuit Learning berbeda dengan yang menggunakan metode konvensional pada saat posttest.
\end{abstract}

Kata kunci: metode pembelajaran circuit learning, hasil belajar

Cara sitasi : Desiana, L., Patonah, R., \& llah. (2021). Pengaruh Metode Circuit Learning Terhadap Hasil Belajar Peserta Didik Pada Mata Pelajaran Ekonomi di SMA, J-KIP (Jurnal Keguruan dan IImu Pendidikan), 2 (3), 69-76. 


\section{PENDAHULUAN}

Belajar adalah kegiatan yang berproses dan merupakan unsur yang sangat fundamental dalam penyelenggaraan jenis dan setiap jenjang pendidikan. Setelah melakukan proses belajar, peserta didik akan mendapatkan hasil belajar Pembelajaran merupakan suatu upaya yang dilakukan oleh pendidik untuk membantu peserta didik agar dapat memperoleh ilmu dan pengetahuan, penguasaan keterampilan, serta pembentukan sikap dan kepercayaan diri pada peserta didik. Menurut Warsita (dalam Abigail, 2017) "Pembelajaran adalah suatu usaha untuk membuat peserta didik belajar atau suatu kegiatan untuk membelajarkan peserta didik". Pembelajaran merupakan upaya siswa untuk dapat belajar dan pengkondisian agar bisa terjadi belajar. Menurut Tari, Suwirta \& Dedeh (2020) Keberhasilan peserta didik dalam mencapai hasil belajar pada setiap peserta didik berbeda-beda. Faktor-faktor yang mempengaruhi keberhasilan peserta didik dalam mencapai hasil belajar dikelompokkan menjadi dua yaitu faktor internal dan faktor eksternal. Faktor internal adalah segala faktor yang berasal dari dalam diri peserta didik, diantaranya kepribadian, motivasi dan sebagainya. Sedangkan faktor eksternal adalah segala faktor yang berasal dari luar peserta didik, diantaranya lingkungan, keluarga, pergaulan, fasilitas belajar, dan sebagainya

Pada kegiatan belajar mengajar guru berperan sebagai fasilitator dan motivator untuk menciptakan lingkungan pembelajaran yang kondusif agar siswa dapat belajar lebih efektif. Kegiatan pembelajaran yang efektif ditandai dengan adanya peningkatan hasl belajar peserta didik yang terwujud dalam perubahan perilaku kognitif, afektif dan psikomotor. Hal tersebut sejalan dengan pendapat Oemar Hamalik (dalam Rusman, 2017) yang menyatakan bahwa: "Hasil belajar itu dapat telihat dari terjadinya perubahan dari persepsi dan perilaku, termasuk juga perbaikan perilaku".

Hasil belajar merupakan salah satu tolak ukur untuk mengetahui keberhasilan belajar peserta didik semakin baik hasil belajar peserta didik maka pembelajaran tersebut dapat dikatakan berhasil. Hal ini sejalan dengan pendapat Dimyati dan Mudjiono, (dalam Wasti, 2013) "Hasil belajar adalah hasil yang dicapai dalam bentuk angka-angka atau skor setelah diberi tes hasil belajar pada setiap akhir pelajaran".

Tinggi rendahnya hasil belajar diantaranya dapat dilihat dari perolehan nilai ulangan harian. Berdasarkan data nilai yang diperoleh dari SMA Negeri 1 Pamarican diketahui bahwa hasil belajar pada mata pelajaran ekonomi kelas $\mathrm{X}$ masih rendah sebagaimana tergambar dalam tabel 1 :

Tabel 1. Data Nilai Ulangan Harian Mata Pelajaran Ekonomi Kelas X IPS SMA Negeri 1 Pamarican Tahun Ajaran 2020/2021

\begin{tabular}{|c|c|c|c|c|c|c|c|c|}
\hline \multirow[t]{2}{*}{ Kelas } & \multirow[t]{2}{*}{ KKM } & \multirow{2}{*}{\multicolumn{2}{|c|}{$\begin{array}{c}\text { Nilai } \\
\text { Terendah Tertinggi }\end{array}$}} & \multirow{2}{*}{ Nilai Rata-Rata } & \multicolumn{2}{|c|}{ Mencapai KKM } & \multicolumn{2}{|c|}{ Belum Mencapai KKM } \\
\hline & & & & & Jumlah & $\%$ & Jumlah & $\%$ \\
\hline X IPS-1 & 75 & 72 & 80 & 74,88 & 16 & 47,06 & 18 & 52,94 \\
\hline XIPS-2 & 75 & 70 & 82 & 77,34 & 18 & 56,25 & 14 & 43,75 \\
\hline XIPS-3 & 75 & 70 & 85 & 78,19 & 20 & 62,5 & 12 & 37,5 \\
\hline
\end{tabular}

Sumber : SMA Negeri 1 Pamarican (2021)

Berdasarkan tabel 1 diketahui bahwa hasil belajar pada mata pelajaran ekonomi masih rendah dengan dibuktikan masih tingginya persentase siswa yang belum mencapai nilai KKM. Salah satu faktor yang diduga menyebabkan rendahnya hasil belajar diatas karena kurangnya terobosan baru dalam penggunaan metode pembelajaran yaitu masih menggunakan metode ceramah. Salah satu metode pembelajaran yang diduga relevan digunakan untuk meningkatkan hasil belajar pada mata pelajaran ekonomi adalah metode pembelajaran Circuit Learning. Menurut Samsiyah (2016:106) "Model Circuit Learning merupakan model pembelajaran inovatif dan kreatif yang bercirikan proses Kegiatan Belajar Mengajar (KBM) yang dilakukan berpusat pada siswa". 
Penelitian sebelumnya (Rinaldi, 2019) menggunakan judul "Pengaruh Model Pembelajaran Circuit Learning Terhadap Motivasi Belajar Siswa Pada Mata Pelajaran Al-Qur'an Hadist. (Studi eksperimen di Kelas VII MTs Nurul Huda Baros Kab. Serang)". Dari penelitian sebelumnya terdapat perbedaan cara meningkatkan hasil belajar peserta didik. Di penelitian sebelumnya metode Circuit Learning difokuskan untuk mendorong motivasi belajar peserta didik sedangkan dalam penelitian ini metode pembelajaran Circuit Learning bukan hanya mendorong motivasi belajar peserta didik namun juga meningkatkan hasil belajar peserta didik.

Hipotesis pada penelitian ini yaitu:

1) Terdapat perbedaan hasil belajar peserta didik yang menggunakan metode pembelajaran Circuit Learning pada pengukuran awal (pretest) dan pengukuran akhir (posttest) di kelas eksperimen.

2) Terdapat perbedaan hasil belajar peserta didik yang menggunakan metode konvensional pada pengukuran awal (pretest) dan pengukuran akhir (posttest) di kelas kontrol.

3) Terdapat perbedaan hasil belajar peserta didik yang menggunakan metode Circuit Learning dengan hasil belajar peserta didik yang menggunakan metode konvensional pada pengukuran akhir (posttest).

\section{METODE PENELITIAN}

\section{Metode Penelitian yang Digunakan}

Metode yang digunakan dalam penelitian ini adalah metode eksperimen dengan desain Quasi Eksperimental Nonequivalent Control Group Design sebagai berikut:

\begin{tabular}{cccc}
\hline Kelas & Pretest & Perlakuan & Posttest \\
\hline Eksperimen & $\mathrm{O}_{1}$ & $\mathrm{X}$ & $\mathrm{O}_{2}$ \\
Kontrol & $\mathrm{O}_{3}$ & & $\mathrm{O}_{4}$ \\
\hline
\end{tabular}

(Sugiyono, 2012:79)

Gambar 1. Desain Penelitian

Keterangan:

$\mathrm{O}_{1} \quad$ : Tes awal (pretest) kelas eksperimen

$\mathrm{O}_{2} \quad$ : Tes akhir (posttest) kelas eksperimen

$\mathrm{O}_{3} \quad$ : Tes awal (pretest) kelas kontrol

$\mathrm{O}_{4} \quad$ : Tes akhir (posttest) kelas kontrol

$\mathrm{X} \quad$ :Perlakuan (treatment) dengan menggunakan metode pembelajaran Circuit Learning pada kelas eksperimen.

Populasi pada penelitian ini yaitu peserta didik kelas X IPS di SMA Negeri 1 Pamarican yang berjumlah 98 orang dan sampel kelas X IPS 2 dan X IPS 3 yang berjumlah 64 orang.

\section{HASIL DAN PEMBAHASAN}

Perbedaan Hasil Belajar Peserta Didik yang Menggunakan Metode Pembelajaran Circuit Learning Pada Pengukuran Awal (Pretest) dan Pengukuran Akhir (Posttest)

Hasil penelitian menunjukan bahwa terdapat perbedaan hasil belajar peserta didik yang menggunakan metode pembelajaran Circuit Learning pada pengukuran awal dan pengukuran akhir. Pada pengukuran awal diperoleh nilai rata-rata sebesar 53,35 dan saat pengukuran akhir diperoleh nilai rata-rata sebesar 86,16 . Nilai $N$-Gain 0,71 termasuk kategori tinggi. Hal ini membuktikan bahwa penerapan model pembelajaran Circuit Learning sangat tepat digunakan pada mata pelajaran Ekonomi pada Kompetensi Dasar Bank Sentral, Sistem Pembayaran, dan Alat Pembayaran dalam Perekonomian Indonesia. 
Peningkatan hasil belajar terjadi karena pada pembelajaran dengan menerapkan metode Circuit Learning pendidik menampilkan peta konsep, melalui peta konsep peserta didik memiliki gambaran materi pembelajaran yang akan dibahas. Selain itu peserta didik mencari materi pembelajaran sesuai dengan peta konsep yang dituangkan dalam bentuk rangkuman sesuai dengan bahasanya sendiri. Peta konsep dan rangkuman memudahkan peserta didik dalam memahami inti materi yang mereka pelajari. Peserta didik menjadi lebih kreatif dalam mengembangkan peta konsep dan lebih berkonsentrasi untuk fokus pada peta konsep yang disajikan guru sehingga hasil belajar peserta didik meningkat. Hal tersebut sejalan dengan pendapat Aris Shoimin (dalam Rafflesines Yuanisa Romaliyana, Made Putra, I Wayan sujana, 2019) beberapa keunggulan metode pembelajaran Circuit Learning yaitu "kreativitas siswa dalam merangkai kata dengan bahasa sendiri lebih terasah dan konsentrasi yang terbangun membuat siswa fokus dalam belajar".

Selain membuat peta konsep dan rangkuman peserta didik kelas X IPS SMA Negeri 1 Pamarican mampu bekerja sama dalam mendiskusikan materi dengan teman sekelompoknya. Melalui belajar berkelompok peserta didik lebih kretif, aktif dan inovatif dalam mengembangkan pengetahuan, sikap dan keterampilannya sehingga proses pembelajaran berpusat pada peserta didik. Peserta didik menjadi lebih kritis dalam berfikir sehingga pada akhirnya berkontribusi terhadap peningkatan hasil belajar. Hal ini sejalan dengan pendapat Karli \& Yuliariatiningsih (2004) beberapa kelebihan belajar berkelompok:

1) Dapat melibatkan siswa secara aktif dalam mengembangkan pengetahuan, sikap, dan keterampilannya dalam suasana belajar mengajar.

2) Siswa tidak hanya sebagai obyek belajar melainkan juga sebagai subyek belajar karena siswa dapat menjadi tutor sebaya bagi siswa lainnya.

3) Siswa dilatih untuk bekerjasama, karena bukan materi saja yang dipelajari tetapi juga tuntutan untuk mengembangkan potensi dirinya secara optimal bagi kesuksesan kelompoknya.

4) Memberi kesempatan kepada siswa untuk belajar memperoleh dan memahami pengetahuan yang dibutuhkan secara langsung, sehingga apa yang dipelajarinya lebih bermakna bagi dirinya.

Hasil diskusi peserta didik beserta kelompoknya berupa rangkuman dalam bentuk peta konsep di presentasikan di depan kelas. Melalui presentasi tersebut peserta didik terlatih untuk mengemukakan pendapat sehingga peserta didik mampu berfikir kritis. Hal tersebut membuat peserta didik mampu memahami lebih jauh materi yang dipelajari sehingga pada akhirnya hasil belajar peserta didik meningkat. Hal ini sejalan dengan pendapat Kozma (dalam Sutrisno, 2009) keunggulan media presentasi yaitu:

1) Presentasi dapat meningkatkan kegiatan belajar dan dapat membantu pemahaman siswa dalam memahami suatu materi.

2) Mendorong siswa untuk berfikir, beraktivitas, bekerja sama dan mengeluarkan pendapat.

3) Merangsang peserta didik untuk mengetahui lebih jauh informasi tentang bahan ajar yang tersaji.

4) Penyajiannya menarik karena ada permainan warna, huruf dan animasi, baik animasi teks maupun animasi gambar atau foto.

Penggunaan metode pembelajaran Circuit Learning menjadikan peserta didik berperan aktif dan bekerja sama dalam kelompok sehingga kegiatan pembelajaran berpusat pada peserta didik. Hal tersebut menjadikan kemampuan berpikir peserta didik menjadi berkembang. Hal ini sejalan dengan Samsiyah (dalam Tumanggor, 2019) yang menyatakan bahwa "Model Circuit Learning merupakan model pembelajaran inovatif dan kreatif yang bercirikan proses Kegiatan Belajar Mengajar (KBM) yang dilakukan berpusat pada siswa".

Pembelajaran melalui metode Circuit Learning berorientasi pada peserta didik dan guru hanya berperan sebagai fasilitator. Guru sebagai fasilitator artinya guru harus memudahkan peserta 
didik dalam kegiatan pembelajaran. Sejalan dengan pendapat Wina Sanjaya (dalam Arfandi \& Samsudin, 2020) menyatakan bahwa "Guru akan memberikan pelayanan yang bertujuan untuk memberikan kemudahan terhadap peserta didik dalam melaksanakan kegiatan belajar mengajar". Peran guru sebagai fasilitator selain memberikan kemudahan dan memfasilitasi peserta didik dalam belajar juga membangkitkan semangat peserta didik. Melalui peranan guru itulah pada akhirnya berkontribusi juga pada peningkatan hasil belajar yang lebih maksimal.

Adapun upaya untuk lebih meningkatkan hasil belajar peserta didik yang menggunakan metode pembelajaran Circuit Learning yaitu setelah kegiatan pembelajaran selesai guru harus memberikan tugas kepada setiap kelompok untuk membuat pertanyaan yang akan di tukar dengan kelompok lainnya sesuai dengan materi yang telah di presentasikan. Hal ini bertujuan untuk mengukur kemampuan peserta didik dalam memahami materi yang telah disampaikan.

\section{Perbedaan Hasil Belajar Peserta Didik yang Menggunakan Metode Pembelajaran Konvensional pada Pengukuran Awal (Pretest) dan Pengukuran Akhir (Posttest)}

Hasil penelitian menunjukan bahwa terdapat perbedaan hasil belajar peserta didik yang menggunakan metode pembelajaran konvensional pada pengukuran awal dan pengukuran akhir. Pada pengukuran awal diperoleh nilai rata-rata sebesar 53,57 dan saat pengukuran akhir diperoleh nilai rata-rata sebesar 64,51 . Nilai $\mathrm{N}$-Gain 0,24 termasuk kategori rendah. Hal ini membuktikan bahwa metode pembelajaran konvensional dapat digunakan pada mata pelajaran ekonomi, namun peningkatan prestasi belajar peserta didik belum optimal karena dalam proses pembelajaran lebih berorientasi pada guru saat proses pembelajaran berlangsung. Hal ini sejalan dengan pendapat Paulo Freire (dalam Yuni, 2021) yang menyatakan bahwa "Pola pembelajaran konvensional tersebut condong kepada jenis pendidikan yang dikatakan dengan istilah bank, yang mana peserta didik dipenuhi serta dijejali dengan beragam materi pelajaran. Peserta didik hanya berlaku menerima semua hal yang sudah serta akan disiapkan oleh pendidik tanpa kegiatan kritis yang lain".

Metode pembelajaran konvensional membuat peserta didik pasif sehingga daya serap terhadap materi pembelajaran lebih rendah. Peserta didik cenderung cepat lupa terhadap materi yang dipelajari karena metode pembelajaran konvensional bersifat menghapal. Selain itu peserta didik mudah jenuh dalam proses pembelajar sehingga pemahaman terhadap materi relatif lebih rendah. Hal ini sejalan dengan pendapat Purwoto (dalam Sitompul, 2019) beberapa kelemahan metode pembelajaran konvensional:

1) Proses pembelajaran berjalan membosankan dan peserta didik menjadi pasif, karena tidak berkesempatan untuk menemukan sendiri konsep yang diajarkan.

2) Kepadatan konsep-konsep yang diberikan dapat berakibat peserta didik tidak mampu menguasai bahan yang diajarkan.

3) Pengetahuan yang diperoleh melalui model ini lebih cepat terlupakan.

4) Ceramah menyebabkan belajar peserta didik menjadi belajar menghafal yang tidak mengakibatkan timbulnya pengertian.

Adapun upaya untuk lebih meningkatkan hasil belajar peserta didik yang menggunakan metode konvensional yaitu ketika pembelajaran di kelas pendidik harus sering melakukan tanya jawab atau berinteraksi dengan peserta didik supaya pembelajaran tidak berlangsung dengan pasif yang membuat peserta didik menjadi lebih cepat bosan. Pendidik dalam menyampaikan materi harus menggunakan bahasa yang komunikatif dan mudah dipahami oleh peserta didik dan materi yang diberikan tidak terlalu banyak, harus singkat, padat dan jelas. 


\section{Perbedaan Hasil Belajar Peserta Didik yang Menggunakan Metode Pembelajaran Circuit Learning dengan yang Menggunakan Metode Konvensional Pada Pengukuran Akhir (Posttest)}

Hasil penelitian menunjukan bahwa peningkatan hasil belajar peserta didik menggunakan metode pembelajaran Circuit Learning lebih tinggi dibandingkan dengan hasil belajar yang menggunakan metode pembelajaran konvensional. Hal ini dapat dilihat dari perolehan nilai $\mathrm{N}$-Gain di kelas eksperimen sebesar 0,71 termasuk kategori tinggi, sedangkan perolehan nilai $\mathrm{N}$-Gain di kelas kontrol sebesar 0,24 termasuk kategori rendah. Artinya metode pembelajaran Circuit Learning lebih unggul dalam meningkatkan hasil belajar peserta didik dibandingkan dengan metode pembelajaran konvensional.

Peningkatan hasil belajar peserta didik dengan metode Circuit Learning lebih tinggi dibandingkan dengan metode konvensional karena dalam pembelajaran menggunakan metode Circuit Learning peserta didik lebih kreatif dalam merangkai kata sesuai dengan bahasanya sendiri dalam mengembangkan peta konsep dan ketika sedang presentasi. Selain itu peserta didik menjadi lebih aktif pada saat proses pembelajaran serta lebih fokus pada peta konsep yang disajikan guru. Hal ini sejalan dengan pendapat Budiyanto (2016) yang menyatakan bahwa " inti pembelajaran Circuit Learning yaitu menciptakan situasi belajar yang kondusif dan fokus, siswa membuat catatan kreatif sesuai dengan pola fikirnya berupa peta konsep dengan bahasa khusus, tanya jawab dan refleksi".

Peningkatan hasil belajar menggunakan metode konvensional lebih rendah dibandingkan dengan yang menggunakan metode Circuit Learning karena dalam metode konvensional proses pembelajaran berjalan satu arah dari guru ke peserta didik sehingga peserta didik lebih pasif, mudah jenuh dan bosan pada saat proses pembelajaran berlangsung yang mengakibatkan hasil belajar peserta didik kurang maksimal. Hal ini sejalan dengan pendapat Purwato (2003) kelemahan metode konvensional yaitu "Proses pembelajaran berjalan membosankan, membuat peserta didik lebih pasif, dan kepadatan konsep-konsep yang diberikan berakibat peserta didik tidak mampu menguasai bahan yang diajarkan".

Hasil penelitian ini membuktikan bahwa semua metode pembelajaran dapat meningkatkan hasil belajar peserta didik. Namun penggunaan metode Circuit Learning lebih unggul dalam meningkatkan hasil belajar dibandingkan dengan metode konvensional. Hasil penelitian ini sejalan dengan penelitian yang dilakukan Nurhasanah (2018) yang menunjukan bahwa "Terdapat pengaruh yang signifikan antara metode pembelajaran Circuit Learning terhadap hasil belajar siswa pada mata pelajaran IPA kelas V SDN 32 Cakranegara".

\section{KESIMPULAN}

1) Terdapat perbedaan hasil belajar peserta didik yang menggunakan metode pembelajaran Circuit Learning pada pretest dan posttest.

2) Terdapat perbedaan hasil belajar peserta didik yang menggunakan metode pembelajaran konvensional pada pretest dan posttest.

3) Terdapat perbedaan peningkatan hasil belajar peserta didik yang menggunakan metode pembelajaran Circuit Learning di bandingkan dengan hasil belajar peserta didik yang menggunakan metode pembelajaran konvensional pada pengukuran akhir (posttest).

\section{REKOMENDASI}

1) Guru hendaknya dapat menerapkan metode pembelajaran Circuit Learning sebagai salah satu alternatif pembelajaran untuk meningkatkan hasil belajar peserta didik pada Mata Pelajaran Ekonomi. 
2) Siswa hendaknya lebih aktif ketika proses belajar mengajar berlangsung agar tujuan pembelajaran dapat tercapai secara efektif.

3) Bagi peneliti lain yang akan melakukan penelitian lebih lanjut, metode pembelajaran circuit learning dapat dipilih secara alternatif terlebih jika proses pembelajaran dilakukan secara tatap muka.

4) Bagi pihak sekolah hendaknya lebih memperhatikan sarana dan prasarana yang dibutuhkan oleh siswa, karena dengan sarana dan prasarana yang mencukupi maka proses kegiatan belajar mengajar akan berjalan dengan baik.

\section{UCAPAN TERIMAKASIH}

Penulis mengucapkan terima kasih yang sebesar-besarnya kepada pihak sekolah terutama Ibu Dra. Hj. Teti Gumiati, M.Pd., selaku kepala sekolah SMA Negeri 1 Pamarican yang telah memberikan izin penulis untuk melaksanakan penelitian dan guru-guru SMA Negeri 1 Pamarican yang telah membantu penulis dalam pelaksanaan penelitian.

\section{DAFTAR PUSTAKA}

Abigail. (2017). Penerapan Model Pembelajaran Discovery Learning untuk Meningkatkan Keaktifan dan Prestasi Belajar Peserta Didik Pada Mata Pelajaran Pengantar Administrasi Perkantoran Kelas X AP 3 SMK Negeri 6 Surakarta Tahun Pelajaran 2014/2015. Jurnal Pendidikan Ekonomi Manajemen Dan Keuangan, Vol. 01 No. 02. [Online]. Tersedia: (https://journal.une sa.ac.id/index.php/jpeka/article/viewFile/1947/1333) [14 Agustus 2021].

Arfandi., \& Samsudin, M. A. (2020). Peran Guru Profesional Sebagai Fasilitator Dan Komunikator Dalam Kegiatan Belajar Mengajar. Jurnal Studi Pendidikan dan Pedagogi Islam, Vol. 5, No. I. [Online]. Tersedia: file:///C:/Users/ACER/Downloads/1200-Article\%20Text-4399-11020210318.pdf [14 Agustus 2021].

Budiyanto. (2016). Sintaks 45 Model Pembelajaran dalam Student Centered Learning (SCL). Malang : Universitas Muhammadiyah Malang Press.

Karli, H., \& Yuliariatiningsih, M. S. (2004). Implementasi Kurikulum Berbasis Kompetensi Jilid 2. Jakarta: Bina Media Informasi.

Purwato. (2003). Evaluasi Hasil Belajar. Yogyakarta: Pustaka Pelajar.

Rinaldi. (2019). Pengaruh Model Pembelajaran Circuit Learning Terhadap Motivasi Belajar Siswa Pada Mata Pelajaran Al-Qur'an Hadist. (Studi eksperimen di Kelas VII MTs Nurul Huda Baros Kab. Serang. [Online]. Tersedia: http://repository.uinbanten.ac.id/5104/ [19 Agustus 2021]

Rizqianna, F., Susanti, Y., \& Andhika, R. Penerapan model pembelajaran avtive knowledge sharing pada mata pelajaran ekonomi di SMA. J-KIP (Jurnal Keguruan dan IImu Pendidikan), 2 (2), 63-70.

Romaliyana, R. Y., Putra, M., \& Sujana, I. W. (2019). Pengaruh Model Pembelajaran Circuit Learning Berbantuan Media Flipchart Terhadap Kompetensi Pengetahuan IPS Siswa Kelas V. International Journal of Educational Policies, Vol.18 (1) Pp. 22-30. [Online] Tersedia: file://C:/Users/ACER/Downloads/22235-34841-2-PB.pdf [14 Agustus 2021]. 
Rusman. (2017). Belajar dan Pembelajaran. Jakarta: Kencana.

Samsiyah. (2016). Pengaruh Penggunaan Model Pembelajaran Circuit Learning Terhadap Hasil Belajar Siswa Pada Mata Pelajaran Bahasa Arab di Mts Swasta Al-Arafah. [Online]. Tersedia: https://bit.ly/3vZ23HG, [11 Januari 2021]

Sitompul, R. E. P. (2019). Perbandingan Hasil Belajar Siswa Dengan Menggunakan Media Benda Konkret Dengan Pembelajaran Konvensional Pada Mata Pelajaran Ipa Di Kelas Iv Sd Swasta Sungai Kehidupan Tahun Ajaran 2018/2019. Skripsi thesis, Universitas Quality. [Online]. Tersedia: http://portaluniversitasqua lity.ac.id:55555/545/ [14 Agustus 2021].

Sutrisno, E. (2009). Manajemen Sumber Daya Manusia Edisi pertama. Jakarta: Kencana Prenada Media Group.

Tari, H. D., Suwirta, U., \& Dedeh (2020) Pengaruh Penerapan Model Pembelajaran Kooperatif Tipe Teams Games Tournament (TGT) Terhadap Hasil Belajar Peserta Didik pada Mata Pelajaran Ekonomi di MAN 2 Kota Tasikmalaya. J-KIP (Jurnal Keguruan dan IImu Pendidikan), 1 (1), 19-26.

Tumanggor, A. J. (2019). Pengaruh Penggunaan Model Pembelajaran Circuit Learning Terhadap Hasil Belajar Siswa Pada Mata Pelajaran Bahasa Arab di Mts Swasta Al-Arafah. [Online]. Tersedia: $\quad$ http://repository.umsu.ac.id/bitstream/123456789/5797/1/SKRIPSI_AS RI\%20pdf.pdf [14 Agustus 2021].

Wasti, S. (2013). Hubungan Minat Belajar Dengan Hasil Belajar Mata Pelajaran Tata Busana Di Madrasah Aliyah Negeri 2 Padang. [Online]. Tersedia: http://ejournal.unp.ac.id/index.php/i het/article/viewFile/1032/869 18 Agustus 2021].

Yuni, H. (2021). Pengaruh Pembelajaran Dengan Model Learning Cycle 5e Terhadap Pemahaman Konsep Fisika Siswa (Studi Pendahuluan Di Madrasah Tsanawiyah Nurul Iman). [Online]. Tersedia: $\quad$ http://repository.uinjambi.ac.id/7531/1/HAFIZHA\%20YUNI\%28 206173301\%29SKRIPSI.pdf [14 Agustus 2021]. 